\title{
Identifikasi Kesalahan Jawaban Mahasiswa Pada Mata Kuliah Trigonometri Berdasarkan Dimensi Pengetahuan Krathwohl
}

\author{
Wahyu Hidayat ${ }^{1 *}$, Usman Aripin ${ }^{2}$ \\ 1,2Program Studi Pendidikan Matematika, Institut Keguruan dan Ilmu Pendidikan Siliwangi, \\ Cimahi, Indonesia; ${ }^{1 *}$ wahyu@ikipsiliwangi.ac.id; ${ }^{2}$ usman-aripin@ikipsiliwangi.ac.id
}

Info Artikel: Dikirim: 15 Maret 2020 ; Direvisi: 22 Maret 2020; Diterima: 25 Maret 2020

Cara sitasi: Hidayat, W., \& Aripin, U. (2020). Identifikasi Kesalahan Jawaban Mahasiswa pada Mata Kuliah Trigonometri Berdasarkan Dimensi Pengetahuan Krathwohl. JNPM (Jurnal Nasional Pendidikan Matematika), 4(1), 142-153.

\begin{abstract}
Abstrak. Penelitian ini bertujuan untuk menganalisis dan mendskripsikan factorfaktor penyebab terjadinya kesalahan dalam menyelesaikan soal-soal trigonometri berdasarkan dimensi pengetahuan Krathwohl. Metode penelitian ini adalah kualitatif dengan jenis penelitian deskriptif. Subjek penelitian yaitu 29 orang mahasiswa program studi pendidikan matematika IKIP Siliwangi. Teknik pengumpulan data yang digunakan dalam penelitian ini adalah tes tulis dan wawancara. Analisis data dilakukan dengan tiga langkah yaitu reduksi data, penyajian data dan penarikan kesimpulan. Hasil Penelitian menunjukan pada dimensi faktual kesalahan terjadi karena kurang hafal rumus-rumus trigonometri yang ada dan sering mengabaikan hal-hal kecil seperti penulisan sudut, satuan sudut dan sebagainya. Pada dimensi konseptual, kesalahan terjadi karena keliru dalam menafsirkan permasalahan dan kurang memahami makna esensial dari setiap konsep trigonometri. Selanjutnya, pada dimensi prosedural, kesalahan terjadi karena kurang teliti dan ceroboh dalam perhitungan dan kurang memahami algoritma perhitungan. Terakhir, pada dimensi metakognitif, kesalahan terjadi karena kurangnya memahami karakteristik setiap rumus dan belum mampu menggunakan pengetahuannya untuk memilih konsep yang tepat untuk menyelesaikan soal. Identifikasi ini dapat digunakan oleh guru untuk membuat rencana pembelajaran dengan memperhatikan keempat dimensi tersebut.
\end{abstract}

Kata Kunci: Dimensi Pengetahuan Krathwohl, Identifikasi Kesalahan Siswa, Trigonometri.

\begin{abstract}
This study aimed to analyze and describe the factors that cause errors in solving trigonometry questions based on Krathwohl's knowledge dimension. The method of this research was qualitative, with descriptive research types. The research subjects were 29 students in the mathematics education study program IKIP Siliwangi. Data collection techniques used in this study were written tests and interviews. Data analysis was carried out with three steps, namely data reduction, data presentation, and conclusion drawing. The results on the Factual Dimension showed that errors occurred because they lack the memorization of trigonometric formulas and often ignored small things such as writing
\end{abstract}


angles, unit angles, and so on. On the conceptual dimension, students' errors occurred because of mistaken in interpreting the problems and lack of understanding of the essential meaning of each trigonometric concept. Furthermore, in the procedural dimension, errors occur due to lack of thoroughness and carelessness in calculations and a lack of understanding of the calculation algorithm. Then, in the metacognitive dimension, errors occur due to a lack of understanding of the characteristics of each formula. They have not been able to use their knowledge to choose the right concepts to solve problems. This identification can be used by teachers to make learning plans with paid more attention to these four dimensions.

Keywords: Krathwohl Knowledge Dimension, Students' Errors Identification, Trigonometry.

\section{Pendahuluan}

Trigonometri berasal dari bahasa yunanni yaitu trigonon yang artinya segitiga dan metron artinya ukuran. Jadi trigonometri merupakan satu cabang dari matematika yang membahas masalah-masalah yang berhubungan dengan segitiga baik itu panjang, luas, keliling ataupun ukuran sudutnya. Trigonometri merupakan ilmu yang berhubungan dengan sudut segitiga dan fungsi trigonometri. Dalam bidang geometri trigonometri, banyak menyumbangkan gagasan-gagasan ataupun solusi dalam mencari panjang sisi ataupun mengukur sudut suatu bidang datar. Selain itu trigonometri dipelajari bukan hanya diperguruan tinggi bahkan di sekolah menengah atas pun dipelajari (Kaliky \& Juhaevah, 2018; Subroto \& Sholihah, 2018; Syahran, 2019). Dengan demikian, mata kuliah trigonometri menjadi dasar atau sebagai prasyarat untuk beberapa mata kuliah seperti kalkulus, geometri analitik, fungsi variabel kompleks dan sebagainya.

Trigonometri sangatlah penting untuk dipelajari karena berhubungan erat dengan kehidupan sehari-hari seperti menghitung ketinggian suatu objek tanpa mengukur secara langsung, sehingga dapat dikatakan sebagai prasyarat untuk mata kuliah yang lebih tinggi (Fatimah, Amam, \& Effendi, 2017; Mulyani \& Muhtadi, 2019; Prasetyani, Hartono, \& Susanti, 2016; Salmina, 2017). Selain itu, trigonometri memberikan kontribusi pada cabang ilmu lainnya seperti navigasi, astronomi, teknik sipil, teknologi pencitraan dalam komputer dan sebagainya. Namun pada kenyataanya mata kuliah trigonometri menjadi salah satu mata kuliah yang di anggap sulit, meskipun sudah pernah dipelajari di SMA.

Berdasarkan pengalaman peneliti dalam mengemban mata kuliah trigonometeri kesulitan mahasiwa bukan bagaimana cara memahami konsepnya tetapi bagaimana cara menyelesaikan sebuah permasalahan yang ada dengan menggunakan konsep/rumus yang ada. Sebagian besar 
mahasiswa masih kebingugan dalam menentukan atau memilih dari sekian banyak rumus yang ada untuk digunakan untuk menyelesaikan permasalahannya. Hal ini sejalan dengan hasil penelitian Subroto \& Sholihah (2018) hambatan belajar pada soal-soal tersebut hampir serupa yaitu siswa belum mampu menggunakan rumus-rumus trigonometri dengan tepat. Hanya sebanyak 62,06\% siswa yang dapat menjawab soal-soal kemampuan pemahaman. Sebagian siswa masih ada yang lupa dalam mengingat rumus dan keliru pada tanda plus dan minus sehingga proses pengerjaan langkah selanjutnya menjadi salah.

Penelitian terkait kesalahan dalam penyelesaian soal-soal trigonometri dianggap suatu hal yang penting untuk dilakukan dalam mengkaji dan merinci permasalahan dalam menyelesaikan soal-soal trigonometeri. Dalam mengkaji sebuah permasalahan tersebut tentu harus ada batasan ataupun parameter yang jelas agar terukur. Salah satunya adalah dimensi pengetahuan Krathwohl.

Dimensi pengetahuan menurut Krathwohl (2002) merupakan hasil pengembangan dan revisi dari taxonomy Bloom. Pada taxonomy Bloom mengembangkan definisi untuk masing-masing dari enam kategori utama dalam domain kognitif yaitu pengetahuan, pemahaman, aplikasi, analisis, sistesis dan evaluasi. Menurut Krathwohl (2002) mengatakan bahwa revisi taksonomi dipertimbangkan secara terminologi dan dirancang untuk mengenali perbedaan psikologi kognitif. Oleh karena itu dari tiga kategori yang ada dimunculkan kategori keempat yaitu pengetahuan metakognitif. Kemampuan metakognitif ini menunjukkan pentingnya dimiliki siswa agar mereka sadar dengan pentingnya aktivitas metakognitif untuk dapat mengontrol pengetahuan yang ada untuk digunakan dalam menyelesaikan permasalahan.

Penelitian terkait analisis kesalahan peserta didik dalam menyelesaikan soalsoal trigonometri sebenarnya sudah banyak dilakukan oleh peneliti sebelumnya. Namun apabila di dalam penelitian tersebut dilakukan pengkategorian berdasarkan dimensi pengetahuan Krathwohl, merupakan suatu hal yang baru untuk dilakukan. Dengan demikian, tujuan dari penelitian ini adalah untuk mengidentifikasi dan menganalisis kesalahan mahasiswa dalam menyelesaikan soal-soal trigonometri berdasarkan dimensi Krathwohl dan mendeskripsikan faktor-faktor penyebab terjadinya kesalahan-kesalahan baik itu kesalahan dalam fakta, konsep ataupun prosedur penyelesaian. 


\section{Metode}

Penelitian ini menggunakan metode kualitatif dengan jenis penelitian deskriptif. Peneliti sering menjumpai kekeliruan mahasiswa dalam menyelesaikan soal-soal trigonometri, oleh karena itu penelitian ini bertujuan untuk menganalisis dan mendskripsikan faktor-faktor penyebab terjadinya kesalahan dalam menyelesaikan soal-soal trigonometri. Partisipan peneliti yaitu 29 orang mahasiswa program studi pendidikan matematika IKIP Siliwangi.

Teknik pengumpulan data yang digunakan dalam penelitian ini adalah tes tulis dan wawancara. Soal tes yang digunakan adalah tes diagnostik berbentuk uraian sebanyak 4 soal uraian terkait materi trigonometri. Kemudian soal tersebut telah divalidasi terlebih dahulu dan di revisi sesuai saran-saran dari para validator.

Soal No. 1

Perhatikan gambar di bawah ini !

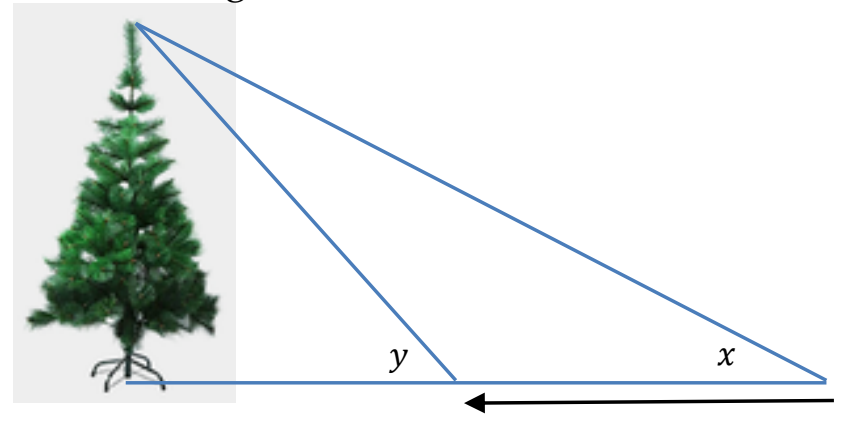

Andi ingin mengukur tinggi pohon dengan menggunkan klinometer untuk menghitung sudutnya. Pengukuran pertama mendapatkan sudut sebesar $x^{0}$ kemudian bergeser mendekati pohon dan melakukan pengukuran kembali dengan sudut $y^{0}$ yang berpenyiku dengan $x^{0}$ dan besar $\sin y=\frac{4}{5}$. Pada akhirnya Andi berhasil menghitung tinggi pohon tersebut yaitu $8 \mathrm{~m}$. Berapakah jarak pergeseran andi pada saat mengukur sudut?

\section{Soal No. 2}

Diketahui $\alpha$ sudut lancip, dan $\beta$ susut tumpul. Jika $5 \sin (\pi+\alpha)+3=0$ dan $\sin \beta=\frac{12}{13}$, maka nilai $\frac{\cos \alpha}{\cos \beta}$ !

\section{Soal No. 3}

Diketahui: $a=\frac{\sin 15}{\sin 75}, b=\sin ^{2} 35+\sin ^{2} 55, \quad c=\cos 20^{\circ} \times \sec 20^{\circ}$, $d=\operatorname{cotan}^{2} 32^{0}-\operatorname{cosec}^{2} 32^{\circ}$. Gunakan sudut bereasi dan identitas trigonometri untuk menentukan nilai paling sederhana dari $a-b-c-d$ ! 
Soal No. 4

Titik A dan B merupakan titi-titik ujung terowongan yang dapat dilihat dari titik C. Apabila besar sudut penglihatan $\angle A C B=45^{\circ}$, jarak titik B ke titik $\mathrm{C}$ adalah $p$ meter dan jarak titik A ke titik $C$ adalah $2 p \sqrt{2}$ meter, maka nyatakan panjang terowongan itu dalam $p$ !

Keempat soal tes ini akan dianalisis berdasarkan 4 dimensi Krathwohl (2002) yaitu: (a) dimensi pengetahuan faktual, siswa harus mengetahui elemen dasar untuk sebuah disiplin atau cara menyelesaikan masalah di dalamnya; (b) dimensi pengetahuan konseptual, keterkaitan di antara unsur-unsur dasar struktur yang lebih besar yang memungkinkan mereka untuk berfunsi bersama-sama; (c) dimensi pengetahuan prosedural, bagaimana melakukan sesuatu, metode penyelidikan, dan kriteria untuk menggunakan keterampilan, algoritma, teknik, dan metode; (d) dimensi pengetahuan metakognitif, pengetahuan kognisi secara umum serta kesadaran dan pengetahuan tentang kognisi sendiri. Pedoman wawancara yang dilakukan untuk lebih mengetahui secara jelas faktor-faktor penyebab terjadinya kesalahan mahasiswa dengan membandingkan dengan hasil jawaban siswa. Selain itu, pada penelitian ini teknik analisis data dengan 3 langkah yaitu reduksi data, penyajian data dan penarikan kesimpulan.

\section{Hasil dan Pembahasan}

Berdasarkan tujuan penelitian ini yaitu mengidentifikasi kesalahan jawaban mahasiswa pada mata kuliah trigonometri berdasarkan dimensi pengetahuan Krathwohl, penelitian ini menganalisis kesalahan-kesalahan jawaban yang terjadi yang ditinjau dari 4 dimensi yaitu faktual, konseptual,prosedural dan metakognitif. Adapun data hasil penelitian yang diperoleh dapat dilihat pada Gambar 1.

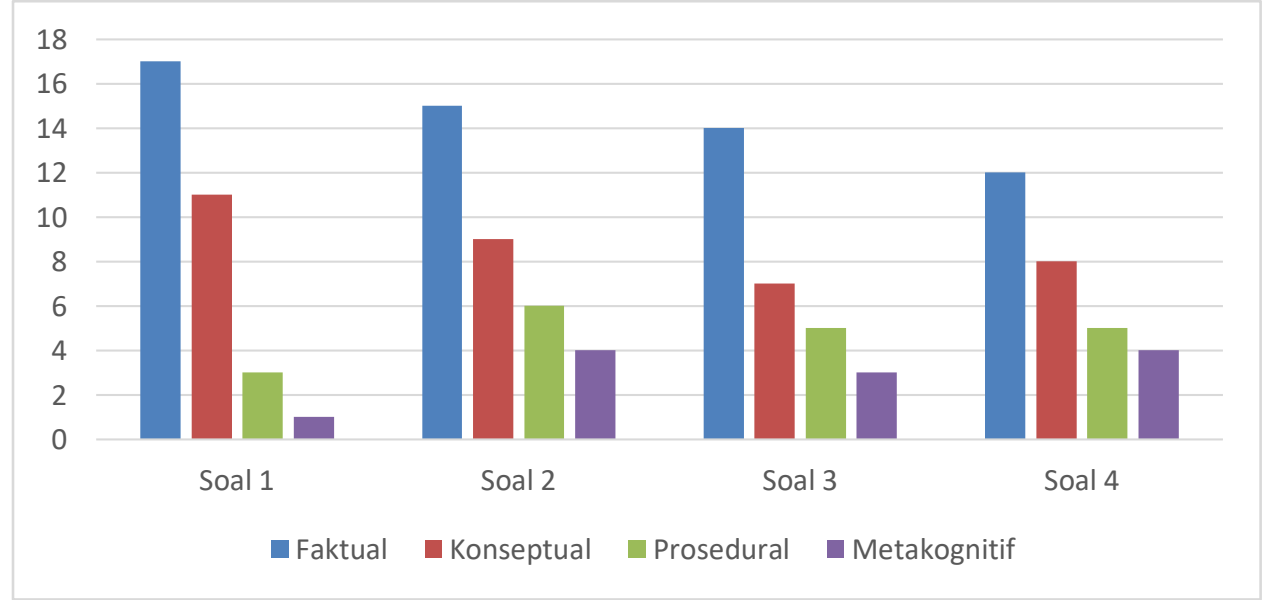

Gambar 1. Hasil Jawaban Mahasiswa dilihat dari Dimensi Krathwohl 
Gambar 1 menunjukkan bahwa dimensi faktual paling tinggi pencapaianya dari semua soal yang ada dan dari 4 dimensi pengetahuan tersebut secara berurutan dari yang tertinggi sampai terendah yaitu, dimensi faktual, konseptual, prosedural dan metakognitif. Apabila dilihat keberagaman semua soal, no 1 soal yang pencapaian presdural dan metakognitifnya paling sedikit namaun dimensi faktual dan konseptual paling tinggi diantara soal yang lain. Hal ini terjadi karena soal no 1 secara konsep sangatlah mudah hanya secara prosedur penyelesaian menajadi sulit karena soal tersebut memerlukan kemampuan metakognitif yang tinggi dimana dalam penyelesaiannya memerlukan strategi dan ide yang kreatif. Metakognitif merupakan aktivitas kognisi sendiri, strategi yang digunkan untuk mengatur proses kognisi sendiri dan keterampilan terhadap bagaimana cara mengarahkan, merencanakan, dan memantau aktivitas kognitif (Anggo, $\underline{2011)}$.

\section{Dimensi Faktual}

Pengetahun Faktual menurut Gunawan \& Palupi (2016) yaitu pengetahuan tentang tentang label dan simbol verbal dan nonverbal (kata, angka, tanda, gambar). Pengetahuan tentang label dan simbol matematika ini merupakan hal yang kurang diperhatikan namun sangatlah penting karena setiap simbol mempunyai makna tersendiri. Berikut ini kesalahan jawaban berdasarkan dimensi faktual dapat dilihat pada Gambar 2.

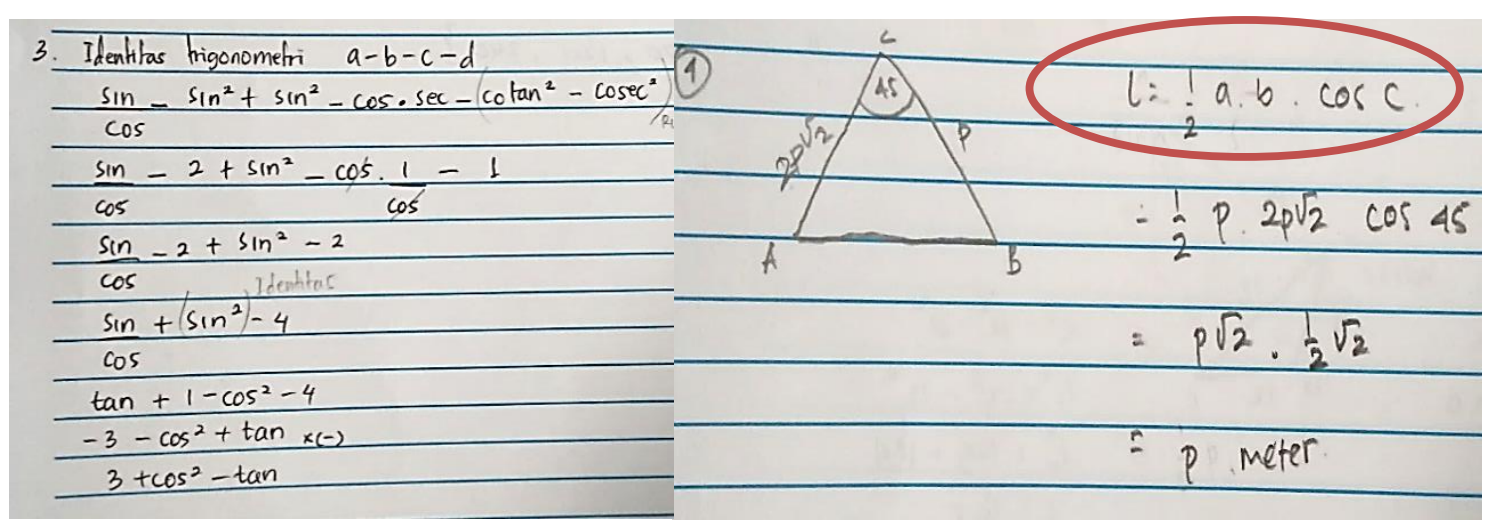

Gambar 2. Kesalahan Jawaban di Tinjau Berdasarkan Dimensi Faktual

Dari Gambar 2 dapat kita lihat masih terdapat kekeliruan dalam menuliskan simbol-simbol trigonometri. Pada soal nomor 1 kesalahan penulisan semua perbandingan trigonometri tidak menuliskan sudutnya. Padahal perbadingan trigonometri tanpa menuliskan sudut itu tidak ada artinya dan tidak ada nilainya. Pada no 4 kesalahan terjadi pada penulisan rumus $L=\frac{1}{2} a b \cos C$ seharusnya rumus itu ditulis $L=\frac{1}{2} a b \sin C$. Namun jika 
dilihat dari apa yang ditanyakan untuk soal nomor 4 jawaban yang diberikan tersebut sangatlah tidak tepat karena pertanyaanya adalah panjang terowongan sedangkan rumus yang dituliskan adalah rumus luas. Dari paparan diatas menunjukan masih adanya kesalahan-kesalahan penulisan simbol matemtika dan keliru dalam memahami fakta yang ada dari permasalahan yang diberikan.

Berdasarkan hasil wawancara yang dilakukan dengan responden didapat kesimpulan bahwa mahasiswa mempunyai kebiasaan mengabaikan terlebih dahulu penulisan sudutnya dan yang terpenting adalah mencari penyelesaianya dan pada akhirnya tidak ditemukan solusinya kemudian jawaban dibiarkan begitu adanya tanpa menuliskan sudut pada perbandigan trigonometri. Selain itu, lupa dengan rumus yang ada dan menuliskan apa yang ia ingat yang sekiranya mendekati dengan apa yang ditanyakan. Faktor utamanya adalah faktor kognitif. Sehingga penyebab kesulitan belajar mahasiswa secara umum dapat dibedakan yaitu kesulitan yang disebabkan oleh faktor kognitif dan non kognitif (Afifah, Nafi'an, \& Putri, 2018). Jadi kesalahan pada dimensi faktual ini terjadi karena mahasiswa belum hafal secara menyeluruh materi yang ada.

\section{Dimensi Konseptual}

Dimensi konseptual merupakan suatu dimensi yang menitik beratkan pada sebuah makna dari suatu pengetahuan yang esensial dari sebuah materi pembelajaran. Dimensi konsep juga dapat berarti sebuah definisi ataupun prnsip yang akan menjadi landasan untuk proses penyelesaian suatu permasalahan.

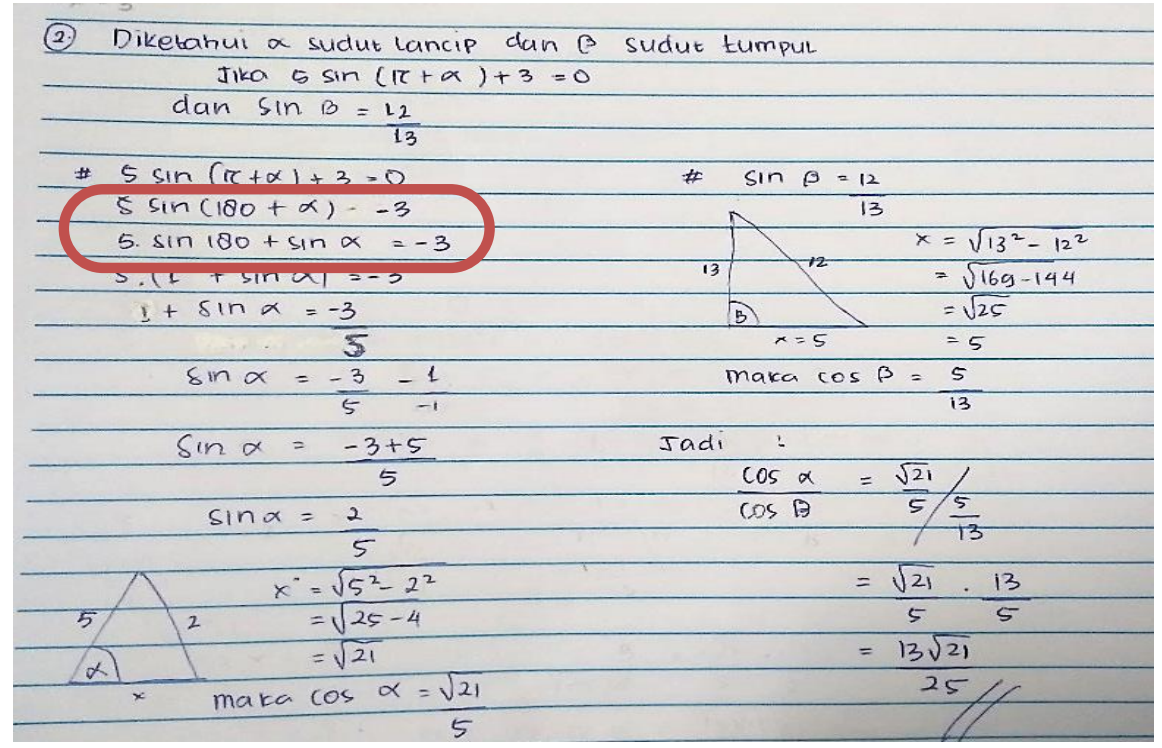

Gambar 3. Kesalahan Jawaban di Tinjau Berdasarkan Dimensi Konseptual 
Gambar 3 menunjukan kesalahan konsep pada rumus sinus jumlah dua sudut yaitu $5 \sin (180+\alpha)=5 \sin 180+\sin \alpha$, yang seharusnya diselesaikan denga konsep sudut berelasi atau menggunakan rumus jumlah dua sudut yang di jabarkan sebagai berikut :

$$
\begin{aligned}
\sin \left(180^{\circ}+\alpha\right) & =-\sin \alpha \ldots \ldots \ldots \ldots \ldots \ldots \ldots \ldots \ldots \ldots \ldots \ldots \ldots \ldots . . .(\text { Konsep sudut berelasi) } \\
\sin \left(180^{\circ}+\alpha\right) & =\sin 180^{\circ} \cos \alpha+\cos 180^{\circ} \sin \alpha \ldots . .(\text { Konsep Jumlah dua sudut) } \\
& =0 \times \cos \alpha+(-1) \times \sin \alpha \\
& =-\sin \alpha
\end{aligned}
$$

Responden menggunakan sifat distributif pada operasi sinus jumlah dua sudut dan penerapan distributifnya pun juga tetap salah karena seharusnya ada 5 sebagai koefisien $\sin \alpha$. Menggunakan sifat distributif pada rumus jumlah dua sudut sangatlah keliru baik secara konsep ataupun makna esensial dari sebuah perbandingan trigonometri. Secara konsep matematis "sin" itu tidak ada artinya jika tidak ada sudutnya dan dalam pengoperasian nilai trigonometri serta bukan merupakan sebuah variabel yang bisa didistribusikan dalam operasi hitung. Selain itu keliru dalam menuliskan sudut seharusnya 180 dituliskan $180^{\circ}$ dengan satuan derajatnya. Penulisan seperti itu akan membingungkan masalah makna esensial dari angka 180 tersebut, apakah itu satuannya derajat atau itu radian.

Berdasarkan hasil wawancara dengan responden dapat di tarik kesimpulan bahwa masih minimnya persiapan sebelum ujian, belum memahami materi pembelajaran dan menyelesaikan soal sesuai dengan rumus yang diingat, seperti bentuk $\sin (180+\alpha)=\sin 180+\sin \alpha$ serupa dengan sifat distributif $a(b+c)=a b+a c$. Hal ini menunjukan mahasiswa salah memahami dan menafsirkan penggunaan sifat distributif. Hal ini sering terjadi, yakni kesalahan dalam menyelesaikan soal matematika salah satunya adalah kesalahan konsep yang merupakan yang dibuat oleh siswa karena salah menafsirkan konsep-konsep, operasi-operasi atau salah dalam penerapannya (Hidayat \& Sariningsih, 2018). Hal ini dikarenakan bahwa pengetahuan konsep merupakan pengetahuan tentang klasifikasi dan kategori, pengetahuan tentang prinsip dan generalisasi dan pengetahuan tentang teori, model, dan struktur. Dengan demikian pengetahuan konsep sangat penting dikuasai karena dengan mengetahui konsep akan dapat mengklasifikasi, membedakan dan menentukan konteks yang tepat dari suatu permasalahan (Afifah, Nafi'an, \& Putri, 2018; Gunawan \& Palupi, 2016; Hidayat \& Sariningsih, 2020). 


\section{Dimensi Prosedural}

Dimensi prosedural merupakan suatu dimensi pengetahuan yang menitik beratkan pada pengetahuan menentukan cara, langkah, dan metode untuk menyelesaikan permasalahan. Agar dapat mempunyai pengetahuan prosedur yang baik haruslah memahami pengetahuan faktual dan konseptual karena apabila tidak dilandasi kedua hal tersebut prosedur yang digunakan memungkinkan keliru karena tidak berdasarkan fakta dan konsep ataupun prinsip yang ada.
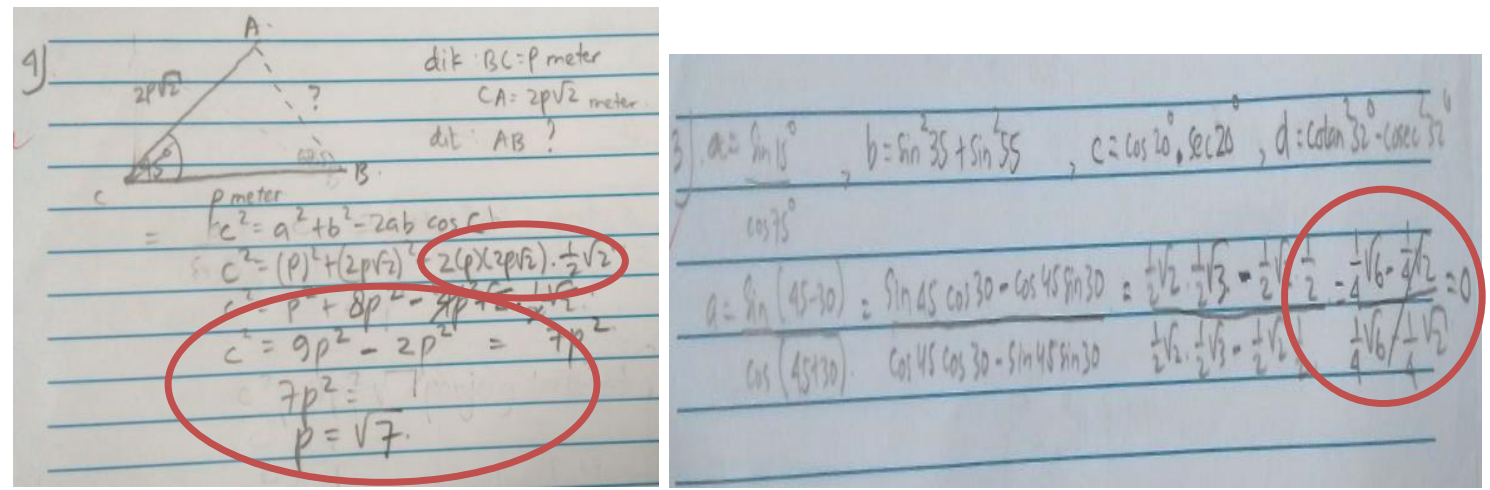

Gambar 4. Kesalahan Jawaban di Tinjau Berdasarkan Dimensi Prosedural

Gambar 4 menunjukan kesalahan siswa dalam prosedur penyelesaian soal namun apabila dilihat dari dimensi pengetahuan faktual dan konseptual, responden sudah mempunyai pengetahuan yang faktual dan konseptual dengan baik hanya keliru dalam algoritma penyelesaiannya. Pada soal nomor 4 responden sudah tepat dalam memahami masalah yang diberikan dengan ditunjukannya ilustrasi gambar dan penggunaan konsep dalam penyelesaian masalah, namun kesalahannya terletak prosedur perhitungan $4 p^{2} \sqrt{2} \times \frac{1}{2} \sqrt{2}=2 p^{2}$ seharusnya $4 p^{2} \sqrt{2} \times \frac{1}{2} \sqrt{2}=4 p^{2}$. Kesalahan pada bagian ini murni karena mahasiswa kurang teliti dalam perhitungan. Selanjutnya pada bagian $c^{2}=7 p^{2}$ dan disimpulkan menjadi $p=\sqrt{7}$ menunjukan prosedur yang salah, seharusnya $c=p \sqrt{7}$. Berdasarkan hasil wawancara dengan rensponden dapat disimpulkan bahwa pada bagian ini responden tidak melihat ruas kiri yaitu $c^{2}$ dan diganti dengan $7 p^{2}=$ dan memindahkan 7 ke ruas kanan selanjutnya di berikan simbol akar didapat $p \sqrt{7}$. Kekeliruan ini terjadi karena responden mengabaikan variabel $c^{2}$, padahal yang sebetulnya di cari adalah nilai dari $c$ akibatnya menjadi salah memahami algoritma perhitungan. Sedangkan pada soal nomor 3 responden sudah menujukan pemahaman faktual dan konseptual yang baik hanya keliru dalam prosedur perhitungannya. Setelah dilakukan wawancara kekeliruan tersebut mengangap bilangan yang sama dibagi dengan cara mencoret keduanya yang berarti habis dan tidak ada nilai. Disini responden keliru 
memahami makna habis di bagi yang artinya hasilnya nol padahal habis dibagi itu artinya tidak ada sisa atau sisannya nol.

Dari hasil analisis diatas didapat dua point utama yaitu: (1) tidak teliti/ ceroboh dalam perhitungan dan (2) kurang memahami prosedur penyelesaian. Salah satu penyebab terjadinya kesalahan mahasiswa dalam menyelesaikan soal-soal trigonometri tersebut, dikarenakan mahasiswa tidak bisa menghafal lagi rumus yang akan digunakan, kurang cermat dalam dalam menjawab soal sehingga jadi salah, kurang teliti dalam menjawab (Abidin, 2012; Hidayat \& Sariningsih, 2018). Dengan demikian dapat dikatakan bahwa salah satu penyebab kekeliruan dalam penyelesaian soal matematik adalah kesalahan hitung, prosedur yang keliru, ketrampilan dasar mengitung dan membaca (Hidayat \& Sari, 2019; Hidayat \& Sariningsih, 2020; Rumasoreng \& Sugiman, 2014; Salmina, 2017).

\section{Dimensi Metakognitif}

Dimensi metakognitif merupakan suatu dimensi pengetahuan tentang bagaimana memainkan semua unsur pengetahuan yang ada dan berhubungan untuk menyelesaikan suatu permasalahan.

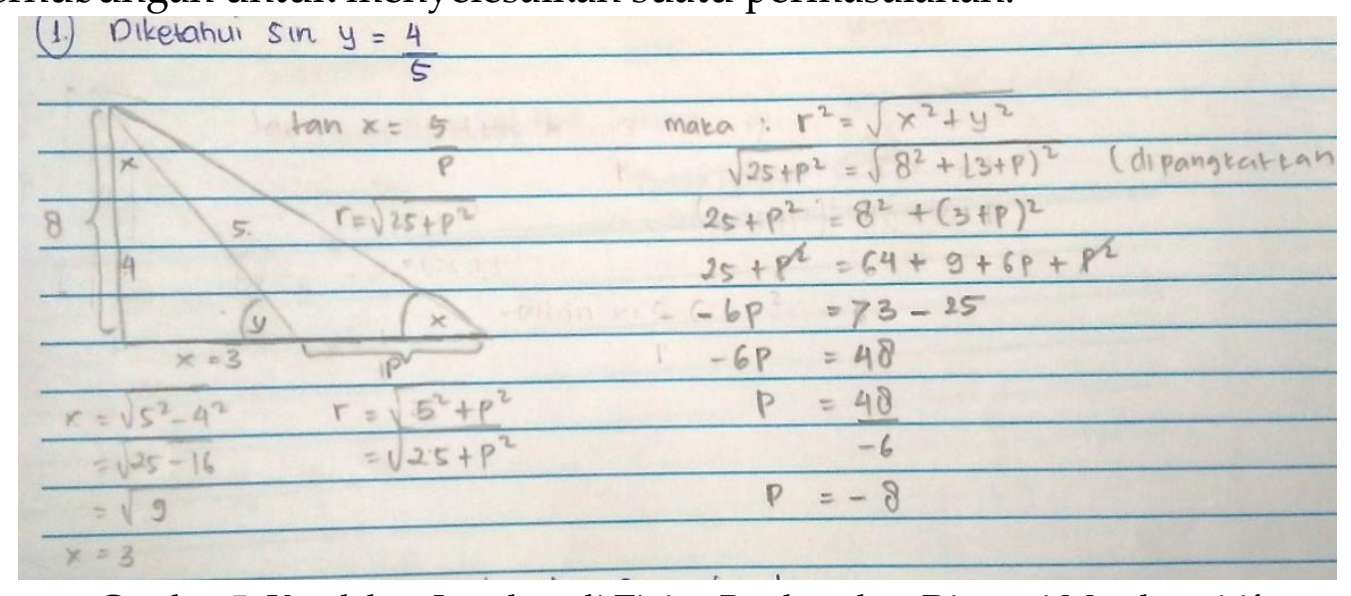

Gambar 5. Kesalahan Jawaban di Tinjau Berdasarkan Dimensi Metakognitif

Gambar 5 soal nomor 1 menunjukan semua prosedur perhitungan benar namun kurang memahami konsep yang berkaitan dengan soal tersebut. Responden sudah mampu meihat apa yang akan di cari dengan mengganti dengan variabel $p$ dan mengilustrasikan pertanyaan dengan konteks yang ada seperti menuliskan sudut $x^{0}$ pada segitiga siku-siku kecil dengan asumsi $x^{0}$ dan $y^{0}$ berpenyiku, meskipun pada soal tidak semua menuliskan sudutsudutnya. Kemudian kurangnya pengetahuan memahami makna perbandingann seperti $\sin y=\frac{4}{5}$ dianggap bahwa panjang sisi-sisinya adalah 3, 4, dan 5 meskipun secara prosedur benar pada saat menghitung panjang salah satu sisinya dengan teorema pythagoras namun tidak mempunyai 
pengetahuan tentang perbadingan. Padahal jelas di soal sudah tertera bahwa tinggi pohon 8 maka sisinya lainnya 2 kali lipat dari apa yang sudah di hitung yaitu, 6, 8 dan 10. Kemudian menghitung sisi miring yang terpanjang dengan konsep pythagoras $r=\sqrt{25+p^{2}}$. Hal ini sangatlah keliru karena panjang sisi-sisi segitiga yang di hitung adalah segitiga tumpul yang artinya tidak berlaku dalil pythagoras.

Kurang pemahaman konsep yang dimiliki peserta didik mengakibatkan kurangnya kemampuan metakognitif. Metakognisi merupakan usaha sadar terhadap aktivitas pengetahuan diri sendiri, metode yang tepat untuk mengatur proses pengetahuannya sendiri dan menguasai bagaimana cara mengarahkan, merencanakan dan memantau aktivitas kognitif (Anggo, 2011). Berdasarkan hasil wawancara dengan responden pada soal ini yaitu miskonsepsi terhadap konsep perbandingan, kurang memahami penerapan rumus-rumus yang ada pada saat mengerjakan soal serta kapan menentukan dan memilih rumus tersebut untuk menyelesaikan soal. Peserta didik harus mengetahui strategi belajar dan berpikir serta mengetahui kapan dan mengapa menggunakan strategi-strategi tersebut dengan tepat (Gunawan \& Palupi, 2016). Dari permasalahan ini mahasiswa perlu untuk meningkatkan kemampuan memahami soal, dapat memahami karakteristik setiap rumus dan mampu menggunakan pengetahuannya untuk memilih dengan tepat konsep yang tepat untuk menyelesaikan masalah (Hidayat \& Sariningsih, 2018).

\section{Simpulan}

Berdasarkan hasil pembahasan, disimpulkan bahwa kesalahan mahasiswa dalam 4 dimensi pengetahuan yaitu sebagai berikut: (1) pada dimensi faktual kesalahan terjadi karena kurang hafal rumus-rumus trigonometri yang ada dan sering mengabaikan hal-hal kecil seperti penulisan sudut, satuan sudut dan sebagainya; (2) pada dimensi konseptual kesalahan terjadi karena keliru dalam menafsirkan permasalahan dan kurang memahami makna esensial dari setiap konsep trigonometri; (3) pada dimensi prosedural kesalahan terjadi karena kurang teliti dan ceroboh dalam perhitungan dan kurang memahami algoritma perhitungan; (4) pada dimensi metakognitif kesalahan terjadi karena kurangnya memahami karakteristik setiap rumus dan belum mampu menggunakan pengetahuannya untuk memilih konsep yang tepat untuk menyelesaikan soal. Identifikasi ini dapat digunakan oleh guru untuk membuat rencana pembelajaran dengan memperhatikan keempat dimensi tersebut. 


\section{Daftar Pustaka}

Abidin, Z. (2012). Analisis Kesalahan Mahasiswa Prodi Pendidikan Matematika Fakultas Tarbiyah IAIN Ar-Raniry dalam Mata Kuliah Trigonometri dan Kalkulus 1. JURNAL ILMIAH DIDAKTIKA: Media Ilmiah Pendidikan dan Pengajaran, 13(1), 183-196.

Afifah, D. S. N., Nafi'an, M. I., \& Putri, I. M. (2018). Analisis Kesalahan Mahasiswa dalam Menyelesaikan Soal Kalkulus Peubah Banyak. MaPan: Jurnal Matematika dan Pembelajaran, 6(2), 207-220.

Anggo, M. (2011). Pelibatan Metakognisi dalam Pemecahan Masalah Matematika. EDUMATICA: Jurnal Pendidikan Matematika, 1(1), 25-32.

Fatimah, A. T., Amam, A., \& Effendi, A. (2017). Konstruksi Pengetahuan Trigonometri Kelas X Melalui Geogebra dan LKPD. JNPM (Jurnal Nasional Pendidikan Matematika), 1(2), 178-188.

Gunawan, I., \& Palupi, A. R. (2016). Taksonomi Bloom-revisi Ranah Kognitif: Kerangka Landasan untuk Pembelajaran, Pengajaran, dan Penilaian. Premiere educandum: jurnal pendidikan dasar dan pembelajaran, 2(2), 98-117.

Hidayat, W., \& Sariningsih, R. (2018). Kemampuan Pemecahan Masalah Matematis dan Adversity Quotient Siswa SMP Melalui Pembelajaran Open Ended.JNPM (Jurnal Nasional Pendidikan Matematika), 2(1), 109-118.

Hidayat, W., \& Sari, V. T. A. (2019). Kemampuan Berpikir Kritis Matematis dan Adversity Quotient Siswa SMP. Jurnal Elemen, 5(2), 242-252.

Hidayat, W., \& Sariningsih, R. (2020). Profil Kemampuan Penalaran Kreatif Matematis Mahasiswa Calon Guru. Jurnal Elemen, 6(1), 108-127.

Kaliky, S., \& Juhaevah, F. (2018). Analisis Kemampuan Berpikir Kritis Siswa Kelas X SMA dalam Menyelesaikan Masalah Identitas Trigonometri Ditinjau Dari Gender. Matematika dan Pembelajaran, 6(2), 111-126.

Krathwohl, D. R. (2002). A Revision of Bloom's Taxonomy: an Overview. Theory Into Practice, 41(4), 212-218.

Mulyani, M., \& Muhtadi, D. (2019). Analisis Kesalahan Siswa dalam Menyelesaikan Soal Trigonometri Tipe Higher Order Thinking Skill Ditinjau dari Gender. JPPM (Jurnal Penelitian dan Pembelajaran Matematika), 12(1), 1-16.

Prasetyani, E., Hartono, Y., \& Susanti, E. (2016). Kemampuan Berpikir Tingkat Tinggi Siswa Kelas XI dalam Pembelajaran Trigonometri Berbasis Masalah di SMA Negeri 18 Palembang. Jurnal Gantang, 1(1), 34-44.

Rumasoreng, M. I., \& Sugiman, S. (2014). Analisis Kesulitan Matematika Siswa SMA/MA dalam Menyelesaikan Soal Setara UN di Kabupaten Maluku Tengah. Jurnal Riset Pendidikan Matematika, 1(1), 22-34.

Salmina, M. (2017). Analisis Kekeliruan dalam Menyelesaikan Soal Kalkulus Pada Mahasiswa Pendidikan Matematika. Numeracy Journal, 4(2), 67-70.

Subroto, T., \& Sholihah, W. (2018). Analisis Hambatan Belajar pada Materi Trigonometri dalam Kemampuan Pemahaman Matematis Siswa. IndoMath: Indonesia Mathematics Education, 1(2), 109-120.

Syahran, S. (2019). Identifikasi Kesalahan Siswa dalam Menyelesaikan Soal Trigonometri di Kelas XI MIA SMA Negeri 3 Alangka Raya. Jurnal Pendidikan, 20(1), 35-50. 